\title{
Measuring the Expectations of Oil Wrestlers with Regards to Oil Wrestling Organizations
}

\section{EmreTüregün \\ Department of CoachingEducation, Duzce University, Duzce, TURKEY}

Key words: Sports organizations, Sports facilities, Sportsadvertisement, Cultural sports

\section{Introduction:}

Every society is entitled to its own sports branches. Oil wrestling is considered to be among the traditional (ancestor) Turkish sports since the time of the old Turkish states in Anatolia, followed especially by the Ottoman period. The etymology of the word "wrestling" (güres), which is found in different dialects of the Turkish language as well (such as, küres or göres), could not yet be discovered. Wrestling, which is based on both body strength and mind power, is as old as human history, being adopted and developed throughout different civilizations. Societies reflected their own cultures to wrestling which resulted in the birth of different types of the sport arising in Egypt, Mesopotamia \& Ancient Greece in 3000 B BC, in Anatolia \& Central Asia in 2500 BC, in India in 2000 BC, and in Japan at 22 BC (Tekin \& Tekin, 2014; Dervisoglu, 2012; Eren, 1990; Güven, 1999). The wrestling figures seen on Egyptian wall paintings dating back to $2000 \mathrm{BC}$ reveal that it has been systematized as a sport branch at least ever since then. Wrestling has been very popular and common among ancient Turks and is known to be performed by the Greeks and Romans as well. Early documents, such as Chinese annuals, epic tales, certain travelogues, and Ottoman history records showed that Turks performed wrestling at a diverse range of occasions, such as celebration festivals and weddings festivities, as well as being a part of war exercises since wrestling is also accepted as a measure of valour. A particular interest of the kings, princes and viziers made wrestling one of the palace (court) sports, along with riding and shooting. It is known that young Turkish women also

\section{Abstract}

The sport of wrestling has a significant place in Turkish cultural history. During the historical evolution of wrestling, Turks have introduced new forms to the sport, which became the traditional norm in time. Currently, oil wrestling is the most common type of traditional wrestling practice in Turkey. This study aims to reveal the expectations of oil wrestlers regarding oil wrestling organisations to put forth the basic requirements of organizations as an input in future planning phases. In this context, a questionnaire has been applied to 541 oil wrestlers for the evaluation of their expectations. The study revealed that the problems of oil wrestlers on wrestling organizations arise from the 4 main components of the facility, advertisement, referee, and award titles.

wrestled in time, while some of them challenged their suitors in horseback racing, arrow shooting and wrestling. The Turkish community enjoyed close contact with one another and being in touch with nature. It has been a time of life struggles in which the individuals try to survive and make themselves safe while living in nature. This struggle for survival has pushed people to fight and to defend attack and defence- through the ages, which made it acceptable for them to show their strength to the society, and/or to prove their superiority.

In the early days, wrestling was considered to be a fight where it is known to result in the death of one of the sportsmen at the end. During the evolution of the sport, such mortal competitions havevanished through time.

Wrestling is divided into the sub-categories such as; aba wrestling, salwar wrestling, karakucak wrestling, and oil wrestling in Turkey. The type that will be examined in this thesis is oil wrestling, where the sportsman wears wrestling pants called kispet, cover themselves in olive oil from head to toe, and carry on the contest in the open air in the countryside. The wrestlers are preferably heavy-weight where the body fat makes it harder for the contestants to hold onto each other. It takes great strength and skill to gain superiority over the opponent. Flatlands suitable for wrestling competitions, such as meadows or plateaus is called the field of a contest -for the brave.

Traditional oil wrestling, which has a long history in the Turkish culture, is amongst the important cultural heritage values of Turkey, and the world as well. As a matter of fact, Kirkpinar Oil Wrestling Festival is the only wrestling

*Corresponding Author: emreturegun@duzce.edu.tr 
organization globally that has entered the UNESCO's Intangible Cultural Heritage list. Kirkpinar masters (aghas) organize oil wrestling organizations with responsibilities including, delegating the sportsman, consolidating the competitions, presenting the awards, hosting the guests from meals to accommodation, and maintaining the overall wellbeing of the attendants and safety of the organization. The studies in the national (domestic) literature mostly cover the history of oil wrestling, the rules of competition, and the historic contests of leading head-wrestlers (Bic, 1944; Sefik, 1953; Temizoglu, 1970; Kaynar, 1971; Ayag, 1983; Kahraman, 1989). Additionally, there are various studies on the history of Çardak and Kirkpinar Oil Wrestling Contents (Gümüs, 1990; Yilmaz, 1995; Acar, 2014). On the other hand, this study aims to examine whether such oil wrestling organizations are up to standards. The answers of oil wrestling contestants in Turkey to the summary list of questions were sought and examined in this study;

. What are the oil wrestlers' expectations regarding wrestling organizations?

- What are the oil wrestlers' general opinions and views on oil wrestling competitions?

- What are the advantages and disadvantages of the facilities utilized in the organizations?

\section{What weanalysed:}

This study utilized the scanning model which aims to describe an existing situation as it was. The event, individual or object that is subjected to research is tried to be defined on its own terms and conditions. Utmost effort was made in order not to influence or affect the subject in any way (Karasar, 2003). The universe of the research consists of oil wrestlers in Turkey. The sample of the study comprises 541 sportsmen who participated in the oil wrestling organizations held in Turkish cities in various regions; namely, Antalya, Edirne, Kocaeli, and Samsun.

The study aimed to reveal the thoughts of oil wrestlers with regards to these sports organizations, including how the events should be organized and how to improve the quality of existing organizations accordingly. Within the scope of the study, an initial focus group meeting was held with 5 oil wrestlers for answering\& discussing 3 open-end questions. The discussion allowed for the generation of survey questions to be developed by a team comprising of the researcher and the sector expert. A total of 35 Likerttype questions regarding the personal information of oil wrestlers and personal opinions on wrestling organizations were created for the study survey which has then been applied to the same samplegroup.

SPSS (Statistical Package for Social Sciences) for Windows Version 25.0 program, which is a tool for statistical analysis with social sciences interface, was used in the analysis of the data obtained as a result of research within the scope of this study. All data obtained were analyzed comparatively, and the results of the analyses were

presented in number and percentage distributions to be explained in summary tables under the appropriate headings in line with the study objectives.

\section{Our findings:}

35 questions regarding the personal information of oil wrestlers and their opinions on wrestling organizations were developed for the study survey to be applied to the sample group of 541 oil wrestlers. This section covers the analysis of all answers given to the related questionnaire.

All the given tables are self explanatory. However, the demographic characteristics of the sportsmen participating in the survey are provided below in Table 1 and Table 2.

Table-1: Distribution of Oil Wrestlers by Age

\begin{tabular}{llllll}
\hline Age Gr. & Frequency & $\%$ & Age Gr. & Frequency & $\%$ \\
\hline $8-14$ & 57 & 10.5 & $15-21$ & 170 & 31.4 \\
$\mathbf{2 2 - 2 8}$ & 168 & 31.1 & $\mathbf{2 9 - 3 5}$ & 74 & 13.7 \\
36 \& $>$ & 54 & 10 & No value & 18 & 3.3 \\
Total & 541 & 100 & & & \\
\hline
\end{tabular}

Table -2: Distribution of Oil Wrestlers by Wrestling Years

\begin{tabular}{llllll}
\hline Age Gr. & Frequency & $\%$ & Age Gr. & Frequency & $\%$ \\
\hline $1-6$ & 220 & 40.67 & $7-12$ & 157 & 29.02 \\
$13-18$ & 78 & 14.42 & $19-24$ & 49 & 9.06 \\
$25 \&<$ & 18 & 3.33 & No value & 19 & 3.51 \\
Total & 541 & 100 & & & \\
\hline
\end{tabular}

Evaluation of Organizational Expectations of Oil Wrestlers within the Scope of Research

In this section, the answers to 32 questions asked under the general heading of the questionnaire, namely "What Are Your Opinions Regarding the Adequacy of Oil Wrestling Organizations?", were investigated with each question's answers assessed separately.

Table-3: Distribution of answers of "Do the Lighting of the facilities is sufficient?"

\begin{tabular}{llllll}
\hline Clause & Freq. & $\%$ & Clause & Freq. & $\%$ \\
\hline Absolutely not agree & 88 & 16.3 & Not agree & 224 & 41.4 \\
Indecisive & 135 & $\mathbf{2 5 . 0}$ & Agree & 65 & 12.0 \\
Absolutely agree & 28 & 5.2 & Total & 540 & 99.8 \\
Missing & 1 & 0.2 & Grand Total & 541 & 100 \\
\hline
\end{tabular}

Table-4: Distribution of answers of "Do the Promotion of organizations is sufficient?"

\begin{tabular}{llllll}
\hline Clause & Freq. & $\%$ & Clause & Freq. & $\%$ \\
\hline Absolutely not agree & 52 & 9.6 & Not agree & 151 & 27.9 \\
Indecisive & 228 & 42.1 & Agree & 73 & 13.5 \\
Absolutely agree & 37 & 6.8 & Total & 541 & 100.0 \\
\hline
\end{tabular}

Table-5: Distribution of answers of "Are the Showers and toilets of the facilities clean?"

\begin{tabular}{llllll}
\hline Clause & Freq. & $\%$ & Clause & Freq. & $\%$ \\
\hline Absolutely not agree & 152 & 28.1 & Not agree & 168 & 31.1 \\
Indecisive & 126 & 23.3 & Agree & 62 & 11.5 \\
Absolutely agree & 29 & 5.4 & Total & 537 & 99.3 \\
Missing & 4 & .7 & Grand Total 541 & 100
\end{tabular}


GENERAL ARTICLE

Table-6: Distribution of answers of "Do the Oil used in oil wrestling is of high quality"

\begin{tabular}{llllll}
\hline Clause & Freq. & $\%$ & Clause & Freq. & $\%$ \\
\hline Absolutely not agree & 110 & 20.3 & Not agree & 150 & 27.7 \\
Indecisive & 195 & 36.0 & Agree & 60 & 11.1 \\
Absolutely agree & 25 & 4.6 & Total & 540 & 99.8 \\
Missing & 1 & .2 & Grand Total & 541 & 100 \\
\hline
\end{tabular}

Table-7: Distribution of answers of "Do the number of changing rooms in the facilities is sufficient?"

\begin{tabular}{llllll}
\hline Clause & Freq. & $\%$ & Clause & Freq. & $\%$ \\
\hline Absolutely not agree & 115 & 21.3 & Not agree & 170 & 31.4 \\
Indecisive & 173 & 32.0 & Agree & 62 & 11.5 \\
Absolutely agree & 18 & 3.3 & Total & 538 & 99.4 \\
Missing & 3 & 0.6 & Grand Total 541 & 100 \\
\hline
\end{tabular}

Table-8: Distribution of answers of "Do the Payments can be made prior to the event?"

\begin{tabular}{llllll}
\hline Clause & Freq. & $\%$ & Clause & Freq. & $\%$ \\
\hline Absolutely not agree & 61 & 11.3 & Not agree & 114 & 21.1 \\
Indecisive & 180 & 33.3 & Agree & 139 & 25.7 \\
Absolutely agree & 46 & 8.5 & Total & 540 & 99.8 \\
Missing & 1 & 0.2 & Grand Total 541 & 100 \\
\hline
\end{tabular}

Table-9: Distribution of answers of "Do the Doping check/test room is provided in organizations"

\begin{tabular}{llllll}
\hline Clause & Freq. & $\%$ & Clause & Freq. & $\%$ \\
\hline Absolutely not agree & 43 & 7.9 & Not agree & 119 & $\mathbf{2 2 . 0}$ \\
Indecisive & 253 & 46.8 & Agree & 94 & 17.4 \\
Absolutely agree & 30 & 5.5 & Total & 539 & 99.6 \\
Missing & 2 & .4 & Grand Total & 541 & 100 \\
\hline
\end{tabular}

Table-10: Distribution of answers of "Do the Floors of the facilities is problematic"

\begin{tabular}{llllll}
\hline Clause & Freq. & $\%$ & Clause & Freq. & $\%$ \\
\hline Absolutely not agree & 35 & 6.5 & Not agree & 160 & 29.6 \\
Indecisive & 170 & 31.4 & Agree & 136 & 25.1 \\
Absolutely agree & 37 & 6.8 & Total & 538 & 99.4 \\
Missing & 3 & .6 & Grand Total 541 & 100 \\
\hline
\end{tabular}

Table-11: Distribution of answers of "Do the Resting areas in the facilities reserved for wrestlers is sufficient?"

\begin{tabular}{llllll}
\hline Clause & Freq. & $\%$ & Clause & Freq. & $\%$ \\
\hline Absolutely not agree & 85 & 15.7 & Not agree & 171 & 31.6 \\
Indecisive & 191 & $35 \cdot 3$ & Agree & 67 & 12.4 \\
Absolutely agree & 27 & 5.0 & Total & 541 & 100.0 \\
\hline
\end{tabular}

Table-12: Distribution of answers of "Are Therespecial seats for the audience in the facilities?"

\begin{tabular}{llllll}
\hline Clause & Freq. & $\%$ & Clause & Freq. & $\%$ \\
\hline Absolutely not agree & 47 & 8.7 & Not agree & 138 & 25.5 \\
Indecisive & 222 & 41.0 & Agree & 101 & 18.7 \\
Absolutely agree & 31 & 5.7 & Total & 539 & 99.6 \\
Missing & 2 & 0.4 & Grand Total 541 & 100 \\
\hline
\end{tabular}

Table-13: Distribution of answers of "Are the Facilities easily accessible?"

\begin{tabular}{llllll}
\hline Clause & Freq. & $\%$ & Clause & Freq. & $\%$ \\
\hline Absolutely not agree & 44 & 8.1 & Not agree & 109 & 20.1
\end{tabular}

Indecisive

Absolutely agree

Missing

185

185
39

Agree

7.2 Total

2

.4 Grand Total 541

99.6

100

Table-14: Distribution of answers of "Are the Facilities suitable for families?"

\begin{tabular}{llllll}
\hline Clause & Freq. & $\%$ & Clause & Freq. & $\%$ \\
\hline Absolutely not agree & 59 & 10.9 & Not agree & 146 & 27.0 \\
Indecisive & 227 & 42.0 & Agree & 85 & 15.7 \\
Absolutely agree & 23 & 4.3 & Total & 540 & 99.8 \\
Missing & 1 & .2 & Grand Total 541 & 100.0 \\
\hline
\end{tabular}

Table-15: Distribution of answers of "Do the Security service is sufficient in organizations?"

\begin{tabular}{llllll}
\hline Clause & Freq. & $\%$ & Clause & Freq. & $\%$ \\
\hline Absolutely not agree & 46 & 8.5 & Not agree & 164 & 30.3 \\
Indecisive & 207 & 38.3 & Agree & 92 & 17.0 \\
Absolutely agree & 30 & 5.5 & Total & 539 & 99.6 \\
Missing & 2 & .4 & Grand Total & 541 & 100.0 \\
\hline
\end{tabular}

Table-16: Distribution of answers to the question of "Is There a hot water problem exist?"

\begin{tabular}{llllll}
\hline Clause & Freq. & $\%$ & Clause & Freq. & $\%$ \\
\hline Absolutely not agree & 130 & 24.0 & Not agree & 136 & 25.1 \\
Indecisive & 183 & 33.8 & Agree & 57 & 10.5 \\
Absolutely agree & 29 & 5.4 & Total & 535 & 98.9 \\
Missing & 6 & 1.1 & Grand Total & 541 & 100.0 \\
\hline
\end{tabular}

Table-17: Distribution of answers of "Do the Announcers shout more than necessary while introducing contestants?"

\begin{tabular}{llllll}
\hline Clause & Freq. & $\%$ & Clause & Freq. & $\%$ \\
\hline Absolutely not agree & 44 & 8.1 & Not agree & 79 & 14.6 \\
Indecisive & 245 & 45.3 & Agree & 111 & 20.5 \\
Absolutely agree & 59 & 10.9 & Total & 538 & 99.4 \\
Missing & 3 & .6 & Grand Total & 541 & 100.0 \\
\hline
\end{tabular}

Table-18: Distribution of answers of "Is there a food problem in organizations?"

\begin{tabular}{llllll}
\hline Clause & Freq. & $\%$ & Clause & Freq. & $\%$ \\
\hline Absolutely not agree & 60 & 11.1 & Not agree & 166 & 30.7 \\
Indecisive & 152 & 28.1 & Agree & 119 & $\mathbf{2 2 . 0}$ \\
Absolutely agree & 42 & 7.8 & Total & 539 & 99.6 \\
Missing & 2 & .4 & Grand Total 541 & 100.0 \\
\hline
\end{tabular}

Table-19: Distribution of answers of "Are the Payments for organizations encouraging?"

\begin{tabular}{llllll}
\hline Clause & Freq. & $\%$ & Clause & Freq. & $\%$ \\
\hline Absolutely not agree & 67 & $\mathbf{1 2 . 4}$ & Not agree & 129 & $\mathbf{2 3 . 8}$ \\
Indecisive & 186 & 34.4 & Agree & 120 & $\mathbf{2 2 . 2}$ \\
Absolutely agree & 39 & 7.2 & Total & 541 & $\mathbf{1 0 0 . 0}$
\end{tabular}

Table-20: Distribution of answers of "Are there enough towels/napkins to be used during oil wrestling?"

\begin{tabular}{llllll}
\hline Clause & Freq. & $\%$ & Clause & Freq. & $\%$ \\
\hline Absolutely not agree & 37 & 6.8 & Not agree & 168 & 31.1 \\
Indecisive & 204 & 37.7 & Agree & 99 & 18.3 \\
Absolutely agree & 33 & 6.1 & Total & 541 & 100.0 \\
\hline
\end{tabular}


Table-21: Distribution of answers of "Do the First aid team is always present during tournaments?"

\begin{tabular}{llllll}
\hline Clause & Freq. & $\%$ & Clause & Freq. & $\%$ \\
\hline Absolutely not agree & 18 & 3.3 & Not agree & 84 & 15.5 \\
Indecisive & 160 & 29.6 & Agree & 211 & 39.0 \\
Absolutely agree & 68 & 12.6 & Total & 541 & 100.0
\end{tabular}

Table-22: Distribution of answersof "Is there any parking service problem at the facilities?"

\begin{tabular}{llllll}
\hline Clause & Freq. & $\%$ & Clause & Freq. & $\%$ \\
\hline Absolutely not agree & 61 & 11.3 Not agree & 191 & 35.3 \\
Indecisive & 190 & 35.1 Agree & 70 & 12.9 \\
Absolutely agree & 27 & 5.0Total & 539 & 99.6 \\
Missing 2 & .4Grand Total541 & 100.0 & \\
\hline
\end{tabular}

Table-23: Distribution of answers of "Are the Shower amenities at the facilities sufficient?"

\begin{tabular}{llllll}
\hline Clause & Freq. & $\%$ & Clause & Freq. & $\%$ \\
\hline Absolutely not agree & 139 & 25.7 & Not agree & 157 & 29.0 \\
Indecisive & 161 & 29.8 & Agree & 56 & 10.4 \\
Absolutely agree & 27 & 5.0 & Total & 540 & 99.8 \\
Missing & 1 & .2 & Grand Total & 541 & 100.0 \\
\hline
\end{tabular}

Table-24: Distribution of answers of "Do the Lack of advertisement results in loss of public interest in oil wrestling?"

\begin{tabular}{llllll}
\hline Clause & Freq. & $\%$ & Clause & Freq. & $\%$ \\
\hline Absolutely not agree & 44 & 8.1 & Not agree & 111 & 20.5 \\
Indecisive & 147 & 27.2 & Agree & 155 & 28.7 \\
Absolutely agree & 83 & 15.3 & Total & 540 & 99.8 \\
Missing & 1 & .2 & Grand Total 541 & 100.0
\end{tabular}

Table-25: Distribution of answers of "Do the Announcers affect the audience negatively?"

\begin{tabular}{llllll}
\hline Clause & Freq. & $\%$ & Clause & Freq. & $\%$ \\
\hline Absolutely not agree & 83 & 15.3 & Not agree & 154 & 28.5 \\
Indecisive & 177 & 32.7 & Agree & 85 & 15.7 \\
Absolutely agree & 38 & 7.0 & Total & 537 & 99.3 \\
Missing & 4 & .7 & Grand Total & 541 & 100.0 \\
\hline
\end{tabular}

Table-26: Distribution of answers of "Do There not any canteen at the facilities?"

\begin{tabular}{llllll}
\hline Clause & Freq. & $\%$ & Clause & Freq. & $\%$ \\
\hline Absolutely not agree & 43 & 7.9 & Not agree & 169 & 31.2 \\
Indecisive & 164 & 30.3 & Agree & 116 & 21.4 \\
Absolutely agree & 49 & 9.1 & Total & 541 & 100.0 \\
\hline
\end{tabular}

Table-27: Distribution of answers of "Do the Referees act is without bias in their decisions during tournaments?"

\begin{tabular}{llllll}
\hline Clause & Freq. & $\%$ & Clause & Freq. & $\%$ \\
\hline Absolutely not agree & 56 & 10.4 & Not agree & 114 & 21.1 \\
Indecisive & 231 & 42.7 & Agree & 106 & 19.6 \\
Absolutely agree & 32 & 5.9 & Total & 539 & 99.6 \\
Missing & 2 & .4 & Grand Total & 541 & 100.0 \\
\hline
\end{tabular}

Table-28: Distribution of answers of "Is there not any drinking water problem at the facilities?"

\begin{tabular}{llllll}
\hline Clause & Freq. & $\%$ & Clause & Freq. & $\%$ \\
\hline Absolutely not agree & 72 & 13.3 & Not agree & 181 & 33.5 \\
Indecisive & 178 & 32.9 & Agree & 87 & 16.1
\end{tabular}

$\begin{array}{llllll}\text { Absolutely agree } & 23 & 4.3 & \text { Total } & 541 & 100.0\end{array}$

Table-29: Distribution of answers of "“Do the Equal respect is shown to all contestants in announcements?"

\begin{tabular}{llllll}
\hline Clause & Freq. & $\%$ & Clause & Freq. & $\%$ \\
\hline Absolutely not agree & 65 & 12.0 & Not agree & 142 & 26.2 \\
Indecisive & 160 & 29.6 & Agree & 127 & 23.5 \\
Absolutely agree & 46 & 8.5 & Total & 540 & 99.8 \\
Missing 1 & .2 & Grand Total & 541 & 100.0 \\
\hline
\end{tabular}

Table-30: "Do the Promotion campaign for oil wrestlers is sufficient?"

\begin{tabular}{llllll}
\hline Clause & Freq. & $\%$ & Clause & Freq. & $\%$ \\
\hline Absolutely not agree & 53 & 9.8 & Not agree & 169 & 31.2 \\
Indecisive & 204 & 37.7 & Agree & 86 & 15.9 \\
Absolutely agree & 29 & 5.4 & Total & 541 & 100.0 \\
\hline
\end{tabular}

Table-31: "Do the Titles of contestants influence the decisions of the referees?"

\begin{tabular}{llllll}
\hline Clause & Freq. & $\%$ & Clause & Freq. & $\%$ \\
\hline Absolutely not agree & 27 & 5.0 & Not agree & 137 & 25.3 \\
Indecisive & 212 & 39.2 & Agree & 123 & 22.7 \\
Absolutely agree & 40 & 7.4 & Total & 539 & 99.6 \\
Missing & 2 & .4 & Grand Total 541 & 100.0 \\
\hline
\end{tabular}

Table-32: Distribution of answers of "Is it offensive to receive payments by hand?"

\begin{tabular}{llllll}
\hline Clause & Freq. & $\%$ & Clause & Freq. & $\%$ \\
\hline Absolutely not agree & 70 & 12.9 & Not agree & 219 & 40.5 \\
Indecisive & 168 & 31.1 & Agree & 66 & 12.2 \\
Absolutely agree & 18 & 3.3 & Total & 541 & 100 \\
\hline
\end{tabular}

Table-33: Distribution of answers of "Are the changing/dressing rooms in the facilities large enough?"

\begin{tabular}{llllll}
\hline Clause & Freq. & $\%$ & Clause & Freq. & $\%$ \\
\hline Absolutely not agree & 99 & 18.3 & Not agree & 163 & 30.1 \\
Indecisive & 193 & 35.7 & Agree & 63 & 11.6 \\
Absolutely agree & 22 & 4.1 & Total & 540 & 99.8 \\
Missing & 1 & .2 & Grand Total 541 & 100 \\
\hline
\end{tabular}

Table-34: Distribution of answers of "Are the meals served at the organization tasty?"

\begin{tabular}{llllll}
\hline Clause & Freq. & $\%$ & Clause & Freq. & $\%$ \\
\hline Absolutely not agree & 65 & 12.0 & Not agree & 187 & 34.6 \\
Indecisive & 195 & 36.0 & Agree & 64 & 11.8 \\
Absolutely agree & 28 & 5.2 & Total & 539 & 99.6 \\
Missing & 2 & .4 & Grand Total 541 & 100.0 \\
\hline
\end{tabular}

Table-35: Distribution of answers of "Do the Range of monetary awards for different categories is wide?"

\begin{tabular}{llllll}
\hline Clause & Freq. & $\%$ & Clause & Freq. & $\%$ \\
\hline Absolutely not agree & 60 & 11.1 & Not agree & 171 & 31.6 \\
Indecisive & 171 & 31.6 & Agree & 83 & 15.3 \\
Absolutely agree & 55 & 10.2 & Total & 540 & 99.8 \\
Missing & 1 & .2 & Grand Total 541 & 100 \\
\hline
\end{tabular}

Table-36: Distribution of answers of "Are the Advertisement posters prepared to attract public from all segments?"

\begin{tabular}{llllll}
\hline Clause & Freq. & $\%$ & Clause & Freq. & $\%$ \\
\hline Absolutely not agree & 55 & $\mathbf{1 0 . 2}$ & Not agree & 79 & 14.6 \\
\hline
\end{tabular}


GENERAL ARTICLE

\begin{tabular}{llllll} 
Indecisive & 259 & 47.9 & Agree & 119 & $\mathbf{2 2 . 0}$ \\
Absolutely agree & 25 & 4.6 & Total & 537 & 99.3 \\
Missing & 4 & .7 & Grand Total 541 & 100 \\
\hline
\end{tabular}

\section{Discussion:}

As per the results of the study, it was observed that oil wrestlers mostly face problems regarding the facilities in which the organizations were held.

The detailed examination of the study results reveal that the facility component of the organizations was substandard overall; dressing/changing rooms in the facilities were not large enough, the shower and WC areas of the facilities were not hygienic, potable drinking water, in addition, too hot water amenity in the showers had been an issue, the recreational and resting areas in the facilities reserved for the wrestlers were unsatisfactory, the proper lighting of the facilities was insufficient, the doping checkroom in the facility did not receive proper care and attention, special seats were not set aside for the audience, the facilities were not suitable for families nor childfriendly, and the access to the facilities that are on the countryside is mainly difficult.

In addition to the facility aspect of organizations, the oil wrestlers state that promotion and advertising of the organization are unsatisfactory which results in loss of interest in oil wrestling by the public. Other problems revealed are; the oil used for oil wrestling is of poor quality, security service is not sufficient for the organization overall, payments were delayed long after whilst they could be made prior to the organizations, the range of monetary awards for different categories were significantly apart, the biased decisions of the referees who care for titles rather than the sport demotivate the sportsman, the announcers may also be prejudiced while introducing contestants and may shout more than necessary overall, there is a limited number of towels/napkins to be used during wrestling, the meals served were unsavoury with inadequate drinking water supply as well.

The above-mentioned issues clearly indicate that oil wrestlers have a negative point of view regarding the wrestling organizations, and such future sports events require more care and attention for thorough planning and operation.

Oil wrestling, as a traditional sport having significant cultural heritage value, the absence of field of the contest -also regarded as "for the brave"- which should reflect the character and historical background of this sport is an important scarcity.
Ambient Science, 2021: Vol. 08h(1); 05-09 DOI:10.21276/ambi.2021.08h.1.ga02

The reflection of this traditional sport in current practices unfortunately neglected as of today. The pioneering of the Ministry of Culture and Tourism (MoCT) and the Ministry of Youth and Sports (MoYS) in the creation and dissemination of good practices of oil wrestling in this regard will certainly provide the base ground for this cultural heritage's journey into the future.

The fact that this study has been the first in the literature to be conducted on the expectations of oil wrestlers with regards to wrestling organizations clarify that the results and evaluations obtained within the scope of the study are original and unique. .

\section{References:}

Acar, A. (2014): Tarihi Çardak Panayi ri ve Yagli Güresleri, Tarafindan yayinlandi: Dahi Yayincilik, Istanbul.

Ayag, A. (1983): Türkler de Spor Gelenegi ve Kirkpinar Güresleri. Tarafindan yayinlandi: Divan Yayinlari, Istanbul.

Bic, M.H. (1944): Türk Güresi. Tarafindan yayinlandi: Marmara Basimevi, Istanbul

Dervisoglu, M. (2012): Kirkpinar Güresleri'nin Halk Bilimi Açisindan Incelenmesi. Yüksek Lisans Tezi, Trakya Üniversitesi, Edirne.

Eren, M. (1992): Güres, Alfabetik Okul Ansiklopedisi, Cilt: 6. Tarafindan yayinlandi: Sabah Yayinlari, Istanbul.

Gümüs, A. (1990): Kirkpinar Güresleri. Tarafindan yayinlandi: Basbakanlik Gençlik ve Spor Genel Müdürlügü Yayinlari, Ankara.

Güven, Ö. (1999): Türklerde Spor Kültürü, 2. Baski. Tarafindan yayinlandi: Atatürk Kültür Merkezi Baskanligi Yayinlari, Ankara.

Kahraman, A. (1989): Cumhuriyete Kadar Türk Güresi, Cilt: 1. Tarafindan yayinlandi: Kültür Bakanligi Yayinlari, Ankara.

Karasar, N. (2003): Bilimsel Arastirma Yöntemi. Tarafindan yayinlandi: Nobel Yayin Dagitim, Ankara.

Kaynar, A. R. (1971): Türkiye Bas Pehlivanlari. Tarafindan yayinlandi: Dizerkonca Matbaasi, Istanbul.

Sefik, E. (1953): Tarihi Türk Güresleri, Istanbul. Tarafindan yayinlandi: Fatih Dernegi Yayinlari, Istanbul.

Tekin, A. \& Tekin, G. (2014): Antik Yunan Dönemi: Spor ve Antik Olimpiyat Oyunlari. Tarih Okulu Dergisi, 7(18):121-140.

Temizoglu, K. (1970): Ata Sporu Yagli Güres ve Kirkpinar. Tarafindan yayinlandi: Mehmet Tunagür Yayinevi, Istanbul.

Yilmaz, T. (1995): Tarihi Kirkpinar Güresleri. Tarafindan yayinlandi: Edirne Belediyesi Kültür Yayinlari, Edirne. 